\title{
Swinney Academic Tree
}

\author{
Tracy Love • Lewis Shapiro
}

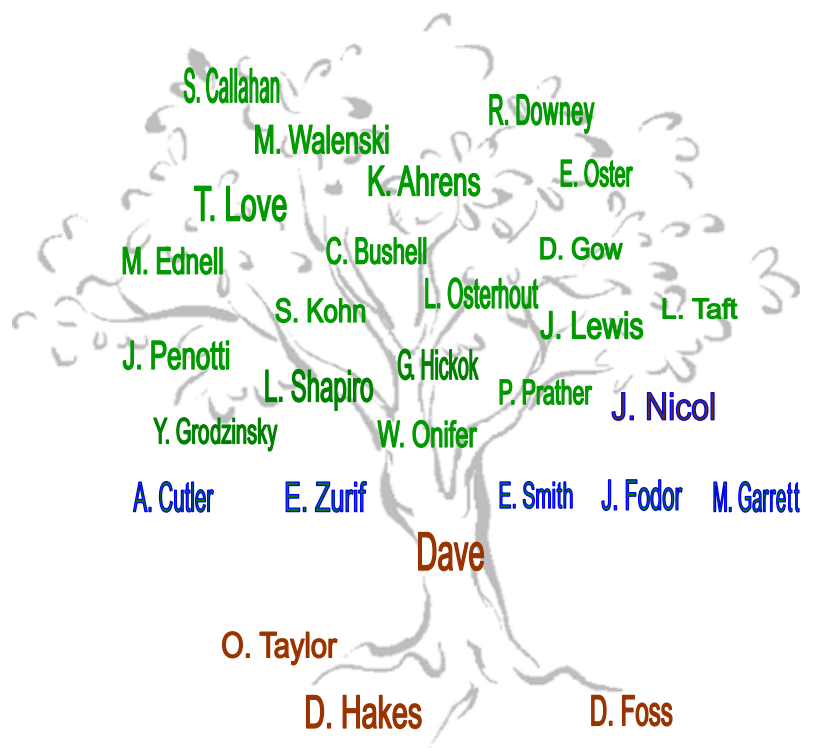

Fig. The David A. Swinney Academic Tree 